\title{
Industrial Relations in Post-coup Fiji: a Taste of the 1990s
}

\author{
Jacqueline Leckie *
}

1990-1 brought a number of major disputes in Fiji's key industries which threatened to escalate. In 1991, the interim government revealed plans to drastically amend labour legislation that would introduce several limitations on the functioning of trade unions and their use of industrial action. The first round of severe restrictions was contained in the National Economy and Sugar Protection Decrees promulgated in May 1991. These were lifted but further decrees in November provided legislation to tighten control over unions and their leaders. This paper places these changes against the economic restructuring in Fiji during the nineties but also emphasises the political basis to this.

\section{Introduction}

The slogan, "Fiji the way the world should be" has since the events of 1987 lost much of its appeal except for perhaps the most diehard and naive tourists. Even staunch Fijian nationalists acknowledge that the country has been beset by economic and political turmoil. The state of industrial relations reflects drastic restructuring, not only affecting the workplace but other aspects of working people's lives. Many of the patterns in Fiji's political and economic transformation reflect changes elsewhere, particularly as a result of the growing internationalisation of capital and labour. Both proponents and opponents of Fiji's industrial and economic restructuring look to models and examples outside the Pacific Islands. Fiji's government may "see the country as becoming a modest South Pacific Singapore" (Islands Business, March 1991, p.16) but its critics point to the limited success of deregulation in New Zealand and Australia. Attempts to implement changes to the economy and labour relations in the island state have by no means been smooth sailing, even when the army was prepared to provide extra 'incentives'. Moves to transform Fiji's industrial climate have coincided with a period of deep-rooted political tensions, in which workers' organisations have been playing a crucial role. ${ }^{1}$

\section{Background}

Trade unions have been legal in Fiji since the introduction of the 1942 Industrial Associations Ordinance, which was designed to encourage the formation of compliant trade unions. There were however several instances of industrial unrest during the colonial period

Department of Anthropology, University of Otago. I would like to thank various officials of the Fiji Trades Union Congress and its affiliates for their assistance. An Otago University Research Grant helped to finance part of the research.

'This paper mainly covers private sector unions. See Leckie 1988, 1990b, 1991 for public sector unions and background to this paper. 
(Leckie, 1990a). The period 1964-66 saw a flurry of legislation being passed to cover trade disputes, workmen's compensation, employment conditions and industrial training. Following in the wake of the disruptive 1959 oil workers' strike, the Trade Unions Act 1964 introduced compulsory registration for trade unions (Leckie, 1990a, pp.58-9). Similar to early British trade union legislation, it contained provisions inhibiting the formation of general unions. Militant industrial unrest also was averted through the somewhat uneven acceptance of power bargaining which brought wage increases and improved employment and living standards for organised workers.

A few years after independence in 1970 saw a growing new wave of industrial confrontation particularly as economic growth in Fiji began to slow (Cameron, 1988, pp.1-5; Leckie, 1988, pp.139). In 1973 the passage of the Trade Disputes Act made it more difficult for workers to take industrial action, especially in essential services. Solidarity strikes were also declared illegal. A wage freeze was also introduced, which subsequently gave way to wage guidelines. This process became negotiable in 1976 with the introduction of tripartism into Fiji's system of industrial relations. Comprising delegates from the national trade union body, the Fiji Trades Union Congress (FTUC), the Fiji Employers' Consultative Association, and government officials, the Tripartite Forum appeared to offer an acceptable means of dispute solving. Unions came to criticise the Tripartite Forum's practice of establishing annual wage guidelines as a means through which employers treated the Forum as a body for imposing wage and salary restraints (Fiji Public Service Association, 1978).

Since 1954 legislation has provided for wages councils to stipulate minimum wages and other conditions of service for low-income workers in specified industries such as manufacturing, building, retailing and hotel and catering. The bulk of Fiji's workers have remained outside even this basic protection as they work within what is loosely termed the 'subsistence' or 'informal' sectors or in family businesses. It is difficult to determine accurate statistics for this, especially as a large number of women are classified as "economically inactive" (Prasad, 1989, pp.3-11). A vast majority of women work in areas not covered by legislation providing for minimum wages and conditions and lack union representation. This particularly applies to paid domestic work which is one of the main occupations for ethnic Fijian and Indo-Fijian women. As discussed below, women have provided most of the labour for the booming garment industry but, until recently, without any statutory wage or union protection.

The intensification of Fiji's economic problems during the early 1980s compounded a growing tense relationship between government and trade unions, particularly in the public sector which underwent prolonged and strained negotiations over salary increases (Howard,1985; Leckie,1990b). By November 1984 tripartism was put to rest with the Minister of Finance announcing a unilateral wage and salary freeze. Since the FTUC had not been consulted over this they withdrew from the Tripartite Forum for the duration of the freeze. Strains in Fiji's industrial relations became seriously acute with Ratu Sir Kamisese Mara, the Prime Minister, threatening to declare a state of emergency and call on the army, if the FTUC proceeded with a general strike (Fiji Times (FT) 10 January 1985). In June 1986 the government withdrew recognition of the FTUC as the national union body on the grounds that the the FTUC had left the Tripartite Forum, although union sources suggested that government's underlying reason was because the FTUC decided in 1985 to sponsor the formation of an opposition political party, the Fiji Labour Party (FLP) (FT, 6 July 1986). While FTUC representatives were still invited to participate on various boards, committees and councils dealing with labour related matters (such as the Labour Advisory Board, the Fiji National Training Council and its training boards and the Wages Councils), government 
extended representation to include unions not affiliated to the FTUC (FTUC 1990a, p.43). Many observers see this as part of a strategy to weaken the dominance of the FTUC in Fiji's labour scene, although official views justify consultation with non-FTUC unions as being more representative of the workforce. However, this is unlikely with the FTUC claiming a membership of around 42,000 in mid-1989, or 35 affiliates out of a total of 46 registered unions in Fiji. ${ }^{2}$

The FTUC also views the lack of government representation at International Labour Organisation (ILO) meetings since 1985 as indicative of the lack of commitment to pursuing labour relations as a tripartite endeavour (FTUC 1990, p.44). Policy relating to the economy and industrial relations was given a new venue apart from the Tripartite Forum, with the establishment of annual National Economic Summits (NES) from February 1985. The FTUC has perceived these meetings, which include representatives from a wide range of economic and community organisations, as little more than a rubber stamp for official and usually predetermined policy.

\section{A taste of the nineties?}

A taste of government's plans to restructure Fiji's economy was given in November 1986 when Mosese Qionibaravi, the Minister of Finance alluded to official plans to deregulate the economy and remove import restrictions. This vision was given a jolt with the economic turmoil unleashed by the May 1987 military coup against the barely month-old FLP/National Federation Party (NFP) Coalition government (see Knapman, 1988). Since then measures to restructure the economy and industrial relations practices have been announced at the NES. Such forums have assumed particular prominence in the absence of parliamentary debate. The August 1990 mini-budget partially deregulated industry to encourage the export-oriented manufacturing sector to become more competitive and efficient through withdrawing subsidies, removing licensing barriers and gradually lowering protective tariffs.

Although such moves evoked considerable disagreement, not only from the FTUC which was adamantly opposed to deregulation, but also between employers (Islands Business, March 1991), the interim administration proceeded with its plans. In the 1991 budget, Josevata Kamikamica, the Minister of Finance and Planning, announced areas of labour and tax reform which would particularly affect workers (FT, 26 November 1990). Wage guidelines were lifted at the end of July 1991 and although this appeared to offer respite from the wage restrictions unions had faced since 1984, government's policy of allowing the market to set wage levels did not augur well for workers. Kamikamica stated that the lifting of wage restrictions was the "first step in reforming the labour market" (FT,1 August 1991), while official proposals at the 1991 NES indicated the strong possibility of abolishing minimum wages in both the unionised and non-unionised sectors. Associated with this was the administration's intention of moving away from government guidelines or industry wide bargaining, to enterprise or establishment level bargaining. Berenado Vunibobo, Minister of Trade and Commerce also raised the strong possibility of abolishing wages councils. Such proposals were particularly worrying for low-income earners when the Minister of Finance

"FTUC, 1990, p.39. Six of those not affiliated were small associations of salaried staff. Hince, 1991, p.57 notes the difficulties in estimating accurate union statistics for Fiji and suggests a union penetration rate in the total workforce of around 43 percent. The 1986 census recorded 80,842 in employment. This included casual workers but excluded cane cutters and domestic workers. 
announced plans to follow IMF recommendations and introduce a value-added tax (VAT) of 10 percent on several goods and services in July 1992.

While the interim administration has been advocating deregulation of the labour market, it has not extended its avowed economic liberalisation to the activities of trade unions. A number of intended reforms to the labour legislation were announced at the 1991 NES summit which were aimed to deal with two faults Kamikamica identified: trade union immunity from prosecution for damages when acting outside the law and the internal functioning of trade unions. Suggested amendments to the Trade Unions Act were to encourage the development of company based unions and tighten up the procedures for determining recognition of trade unions. Recommended changes to the Trade Disputes Act included a wider definition of a strike to include forms of industrial action such as a go-slow, work-to-rule, or withdrawal of goodwill. Amendments to the Industrial Associations Act were designed to disallow industrial associations from acting as trade unions. This clearly was aimed at restraining one of Fiji's strongest industrial associations, the National Farmers' Union (NFU), and curtailing the growing industrial muscle demonstrated by Fiji's newest industrial association, the Fiji Association of Garment Workers.

Specific proposals which would effectively make trade union recognition, recruitment and organisation more difficult also included proposed amendments to the Trade Union (Recognition) Act to abolish the legal requirement for employers to deduct union dues from employees, the introduction of secret ballots and the introduction of time limits on the validity of strike ballots.

\section{The rationale for labour reform}

It is suggested that the administration's rationale for implementing labour reforms stems primarily from their broader economic policy and desire to curb trade union opposition to this. The aim of controlling trade union activities and, as many unions argue, to weaken them, is also part of an ongoing response to union opposition to the regime. Union opposition has not just been directed at employment matters, but has embraced broader political issues, such as the legitimacy of Fiji's new constitution. However motives for advocating reforms were couched in other reasons given by government ministers. To justify proposals to abolish minimum wages and wages councils, Vunibobo argued that employment opportunities would be generated which would help alleviate poverty. Poverty in Fiji has become a politically contentious issue with estimates of approximately $15-20$ percent of Fiji's population in absolute poverty and a higher proportion considered to be in relative poverty (Barr 1990). Kamikamica's case for labour reform was presented in culturalist terms:

I see the biggest challenge now facing Fiji as being in the area of labour market reform, where the cultural traditions of our ethnic groups here mingle with the cultural and ideological traditions of Europe in an often uncomfortable combination (NES papers 1991, p.17).

He then went on to say that "The challenge for government is to ensure an economic environment in which competitive business can operate."

This latter statement points towards the administration's more fundamental economic objectives, for which the restructuring of the labour market was deemed necessary. Official policy sought to encourage the growth of export production, and as discussed below, industrial unrest could threaten investment and production within the tax-free export sector. Workers had also shown, in the building industry, for example, that they would not take redundancies 
lightly, while unions had already indicated their strong opposition to proposals for a minimum wage, the abolition of wages councils and the introduction of a goods and services tax. Public sector workers, especially the Fiji Public Service Association (FPSA), had on several occasions threatened industrial and legal action to oppose government moves to corporatise government departments and statutory bodies. The corollaries of this were the proposed reforms on the operation of trade unions, and also the introduction in May of stringent legislation bent on curtailing disruptive industrial action. Kamikamica clarified that the deregulation of wages "without also ensuring mechanisms in place to ensure that the resulting freedoms are not abused, could be a formula for chaos" (NES papers).

The rationale for further legislative reforms to control trade unions was also encased in ambiguous terms. For example, Vunibobo claimed that proposals to introduce postal or workplace ballots for the election of union officials would make leaders more representative to their members. But the wider reasons for such reforms were clearly spelt out: "reform was essential because of the risks of industrial disruption which would severely set back economic growth" (NES papers).

\section{Fiji's 'showpiece': industrial relations and tax-free factories}

The focus of the interim administration's economic policy has been the development of tax-free factories, which among other benefits enjoy a 13 year tax holiday and are able to repatriate capital and profits. Although mooted as a solution to Fiji's economic problems during the late seventies, they were not established until after the second coup in 1987 (see Chandra, 1988). Plans currently are also underway for the establishment of a separate export processing zone. The main growth area of employment since the coups has been in manufacturing. By mid-1991 garment workers comprised 83.3 percent of 10,917 employed in 113 tax-free factories (Reserve Bank of Fiji, News Review 21 August 1991: 8(34)). This represented at least 12 percent of those in paid employment. With forecasts of initially providing 2000 jobs and ultimately generating 8000 positions, Fiji's proposed tax-free zone is heralded as a salvation to growing poverty and unemployment problems ( $F T, 20$ September 1990). Prasad (1989, p.34) has been more cautious in assessing the impact of tax-free factories, noting that while the garment industry has provided much of the new employment since the coups, considerable growth had been underway before garment factories were granted tax-free status and that it has depended heavily upon female labour not formerly considered as in the labour market.

One of the initial attractions of Fiji's tax-free factories was the promise by a military regime that unions would be excluded. Compliant labour relations also seemed more likely with a predominantly female multiethnic workforce that often was unaccustomed to regular employment and generally had little direct experience of unionisation. The economic dislocation and high unemployment (Reserve Bank figures gave 10 per cent for 1987) after the coups also reinforced management control in these factories. Despite this, the administration backed down on its earlier plans to bar unions from the tax free factories.

It took until 1990 for cabinet to announce the establishment of a separate Garment Industry Wages Council, which introduced a minimum hourly wage of 65 cents for apprentices and 85 cents for other workers. Other conditions such as working hours, overtime, payment for public holidays and sick leave were also covered (FT, 3 January 1991). This met with opposition from many manufacturers and the FTUC which claimed that it had not been 
consulted, that the correct procedures to enforce the rates had been ignored and that the rates were too low. The minimum rate gives a net pay of $\$ 25$ a week out of which workers, many being sole income earners for their families, would have to meet expenditure for food, housing, transport, electricity, water, children's education and other necessities ( $F T, 3$ November 1990).

It is not surprising that with the continuation of wages frequently well below a basic poverty level of $\$ 72$ a week or the estimated average national wage of $\$ 50$ a week for an unskilled worker ${ }^{3}$ and with working conditions considered by many to be 'sweated,' that workers both within and outside the garment industry have been agitating for better pay and conditions. A report by the Ministry of Employment and Industrial Relations (MEIR) found that almost two-thirds of surveyed factories paid less than 51 cents an hour and four-fifths avoided paying overtime (Cole, 1991). Esiteri Tuilovoni, Secretary of the Fiji Association of Garment Workers, confirms that even the minimum wages and conditions of the wages council are not being enforced. This is particularly difficult to do when manufacturing is sub-contracted to family businesses or when employers transfer workers to another enterprise to avoid paying full-rates after the six month training period. Manufacturers also maintain it is often necessary to have long work-shifts if export deadlines are to be met. Other complaints, such as sexual harassment, are even more difficult to report and enforce.

While such practices are still widespread, both the interim government and some manufacturers have become somewhat more sensitive to the tarnished image that sweated labour can project abroad. In spite of an official delay of eight months, the Fiji Association of Garment Workers (FAGW) was formally registered in 1989 and in 1990 had around 1152 members (FTUC, 1990, p.94). Employer recognition has been even slower and rarely is considered until after garment workers have taken industrial action.

The second half of 1990 saw a number of unprecedented strikes in which the FAGW was involved. In September 1990, 75 garment workers from an Australian owned shirt making factory, Mark One Apparel, walked away from their machines because of management's failure to deliver promised pay increases or provide sick pay, and the alleged continuation of discriminatory bonus payments (FT, 4 September 1990). Mark Hellaby, the manager, argued that efficiency was low at the factory although workers suggested that if they were paid the same wages as his employees in Australia, their output would increase: "You give us the incentive and we'll give you the work ethic." After three days a compromise was reached over the pay increase.

However in October 1990 a 15 day strike by approximately 400 workers at the Just Cham Garment Company (a joint venture with a New Zealand Company Alex Young) appeared to escalate with Ema Druavesi, past-Secretary of FAGW, threatening a national strike by garment workers, the FTUC threatening a boycott of the factory and the company warning that it would dismiss the strikers (FT, 20 October 1990; 22 October 1990). With wages averaging \$20 a week, low pay was again a central issue, but the workers list of 24 grievances included complaints about inadequate toilet facilities, excessive overtime without extra payment or transport being provided, no annual leave, no tea breaks, excessively heavy work, no employer responsibility for accidents or sick leave and the practice of strip searching if any items went missing (FT, 10 October 1990). The FTUC claimed that any worker who

${ }^{3} \mathrm{Barr}(1990)$ suggests this is the basic salary necessary to purchase a minimum nutritious diet for a family of six and ensure basic necessities. He contends that mean wage rates overestimate the wages most workers receive, especially in the 'informal sector'. 
complained about conditions to the Employment Ministry would be sacked.

Industrial unrest continued to rock the garment industry in 1991. In March 1991, around 85 workers at Hennessey Limited and around 90 women from Apparels (Fiji) Limited went on strike (FT 5 March 1991; 6 March 1991). Non-recognition of the FAGW was a central issue here, along with claims of workers' victimisation. Alisi Qaranivalu, a supervisor at Hennessey, claimed she was unfairly dismissed after management refused to increase her wages in accordance with the wages council order, while Neema Singh, the chief quality controller at Apparels said she was dismissed because of her position as President of FAGW's Nadi branch. Although these actions may have precipitated the strike, workers' grievances also stemmed from poor working conditions. Union officials claimed that management at these factories were violating not only the new wages council order, but also the 1971 Factories Act. A worker complained:

They're treating us like slaves. It gets so hot and stuffy in there. It just gets unbearable having to work without proper ventilation and it's ridiculous not being allowed to go to the toilets when you want to (FT, 5 March 1991).

The strike at the Hennessey factory also appeared to reveal how production and profitability within the export sector can be acutely sensitive to sudden industrial disputes. It also indicated how manufacturers have become increasingly flexible in closing and restarting factories according to labour costs and the compliability of the workforce. Hennessey management took only one day to decide to close down. This was ostensibly in response to the withdrawal of Hennessey's main contractor although only two weeks later with the new name of OZII Limited, new Australian partners, a new workforce and a new product, upholstery, the factory was back in operation, in spite of FAGW opposition (FT, 21 March 1991). Regarding an earlier strike at Lotus Garments, Gary Sutton, a New Zealand garment importer warned that if industrial unrest there spread to other garment factories, overseas importers and manufacturers would "merely go elsewhere" (FT, 16 November 1990). The Fiji government and garment manufacturers became especially sensitive to the ramifications of industrial stoppages within the garment industry with changes in Australian import policy to reduce tariffs on imports from non-Forum Pacific Island countries (FT, 15 March 1991).

Part of the interim administration's rationale for introducing labour reform, as noted, was to control industrial unrest and the power of unions. Official statements also indicate how the state's industrial relations policies were tied in not only with the economic but also the political agenda. Strikes within the garment industry have particularly been labelled by the interim government's spokespersons as being politically motivated. Navi Naisoro, the Permanent Secretary for Trade and Commerce, stated that his ministry believes "the strikes in the garment industry are being carefully orchestrated to undermine the government." To justify this he cited how the Mark One Apparel strike coincided with the opening of the Australian-Fiji Business Council meeting in Nadi and suggested the Just Cham strike was aimed at undermining the government's position in current negotiations underway in the USA (FT, 11 October 1990). Clearly government was also sensitive about the international trade union links garment workers were developing, such as when Mahendra Chaudhry, General Secretary of the FTUC threatened to call upon overseas solidarity support and lobby the governments of Fiji's garment export markets (FT, 12 October 1991). Druavesi again threatened an international black ban when the MEIR rejected a dispute over the dismissal of three union activists from Lotus Garments (FT, 2 November 1990) Around 100 workers went on a 28 day strike over this and what they described as "appalling working conditions and extremely long hours", of sometimes up to 24 hours, although Padam Lala, the manager denied this. 
FAGW sources have rejected any deliberate conspiracy to undermine Fiji's administration and stressed the long-term and industry-wide grievances of the strikers and the "ordinary daily crises arising from every factory" (Interview, Tuilovoni). The FTUC suggested that government was the one hiding behind "political smokescreens" and that official reluctance to intervene was tied in with "many top government officials including some ministers" who had "pecuniary interests in garment factories either directly or through indirect shareholding. This is why government has sat back and watched exploitation of its people by unscrupulous industrialists" (FT, 17 November 1990).

Although the interim administration's policies and practices have reinforced employer resistance to unionisation and to improved pay and working conditions in the garment industry, there has been, following industrial unrest, some improvement in wages and conditions within the garment industry. Some employers, such as Lala (President of the Garment Manufacturers' Association) have recognised the FAGW and signed a collective agreement. Many of the industrial disputes have been resolved through conciliation.

Media attention has also put pressure on the MEIR to investigate violations of the Fiji Employment Act and the Factories Act. These have been applied particularly to violations of health and safety regulations and the illegal employment of women in factories after 8pm. However, official willingness to take action on this has been slow. For example, although MEIR confirmed complaints that female workers from South Island Apparels were forced to work until $12.30 \mathrm{am}$ each night, officials avoided prosecution, arguing that it was wrong to move against one employer when others might be breaching the act. The FTUC claims that this employer should be prosecuted so that the case could be a deterrent: "It clearly shows the anti-worker attitude of the Labour ministry and the fact that it is protecting the employers" (Fiji Labour Sentinel, March 1991). Instead the MEIR began a nationwide investigation into the hours of employment of garment workers.

\section{Industrial relations by decree}

On 29 May 1991 workers and their union representatives in Fiji were not taken by too much surprise when the interim administration announced the promulgation of the Sugar Industry (Special Protection Amendment No 3) Decree 1991 and the Protection of the National Economy Decree 1991 (Fiji Republic Gazette 5 (37), Decrees No. 18 and 19).

Although the interim administration's plans to deregulate the labour market and introduce several measures to control the operations of trade unions exacerbated the already smouldering discontent within Fiji's industrial relations, the severity of the sugar and economy decrees drew the most shock and condemnation and introduced the possibility of an explosive confrontation. While Decree No. 18 applied to the protection of all aspects of sugar production, No. 19 applied to the protection of the whole economy of Fiji, with special reference to the protection of the tourism, copra, sugar, mining, oil, transport, telecommunications and electricity industries. Both decrees referred to not only those directly involved in hindering the operation of these industries but also anyone "who counsels, incites or encourages a person to commit any act or omission that harms the operation of a major industry which threatens or is likely to threaten the economic life of Fiji" (Decree 19: 3(2)). Such responsibility was deemed to cover citizens within Fiji or abroad and residents within Fiji. The penalties? Trade union members engaging in industrial action which prevented an industry from operating, could expect a fine of $\$ F 10,000$ or a sentence of 14 years or both, 
while those taking solidarity action could anticipate a fine of \$F5000 or 7 years imprisonment or both. The latter ostensibly could have been applied to a vast range of activities, from imposing trade and communication bans to supplying food or distributing leaflets for striking mine workers. These decrees also aimed to prevent militant international solidarity action.

\section{The 1991 sugar harvesting crisis}

The Sugar Industry Protection Decree 1991, reflected the extent to which industrial unrest has rocked Fiji's main export industry. Heated tensions between sugar growers, cane cutters and mill workers and the sugar millers was nothing new and on several instances, the state had intervened to ensure that the industry was protected (Gillion, 1977; Plange, 1990) if sugar growers implemented their most effective form of industrial protest by refusing to cut cane. This was exactly the action taken in June 1991 by the majority of Fiji's cane farmers. Led by the NFU, the boycott was directly provoked by the Fiji Sugar Corporation's (FSC) refusal to pay farmers a promised third cane payment for the 1990 harvest. NFU discontent stemmed not only from the position taken by the FSC, but also from government's policies (or lack of them) in the sugar sector. Tension had also been strong between the farmers and the Sugar Cane Growers' Council. Strong objections were made by the NFU to government's decision to delay council elections, already suspended in 1988, until April 1992. Chaudhry considered these elections might be scrapped (FT, 22 January 1991) and maintained that farmers had no confidence in their official representatives. These antagonisms were heightened during the sugar harvest boycott when government refused to enter into dialogue with the NFU, reiterating that all growers grievances had to be channelled through the council.

These grievances may have directly precipitated the boycott but there were far deeper tensions within the sugar industry, before and during 1991. Cane farmers had delayed the 1990 harvest in protest at provisions of a new Sugar Award (the Kermode Master Award) which Chaudhry argued was biased towards the FSC and reduced the farmers' share of the sugar proceeds from 70-75 percent to 60 percent by passing on extra harvesting and transport costs to the farmers (FT, 11 June 1990). During this dispute the NFU, rather than the growers' council, commanded the support of most of Fiji's 22,000 cane farmers (1991 membership of the NFU is around 11,000). Although a compromise settlement was reached, tension continued especially with further delays caused by mill inefficiency.

The complexity of the composition and aims of the factions within the sugar industry are too detailed to enter into lengthy discussion here. Some points require clarification, because any major crisis in the sugar industry invariably becomes entwined in Fiji's broader industrial climate. The Fiji government might claim that the sugar growers' associations are not trade unions, but they were registered under the Industrial Associations Act under which until November 1991, the definition of an industrial dispute included "any dispute or difference between sugar-cane farmers and sugar manufacturers" (see ILO, 1982, p.8).

Political developments during the past few years have heightened the prominent role taken by the NFU. Although many members were and still are staunch NFP supporters, most accepted the FLP/NFP Coalition established before the 1987 general elections. Many cane farmers have changed their allegiance to the FLP, particularly as NFU General Secretary, Mahendra Chaudhry, played a central role in the new Labour Party. Following Sitiveni Rabuka's overthrow in 1987 of Bavadra's short-lived government, cane farmers organised through Chaudhry and the NFU demonstrated the power of industrial muscle when they refused to cut cane. Simultaneously, Chaudhry was one of the main proponents in the FTUC 
calling for the maintenance of international trade union bans on Fiji. To the outside observer, sugar growers may appear to have different interests to industrial workers, but they have played a key role in Fiji's industrial climate and labour movement. Cane farming communities, especially those of Indian descent, face considerable insecurity with land leases due to expire in 1997. Chaudhry's role as a linchpin between cane growers and other workers was strengthened by his election in 1988 as General Secretary of a more militant FTUC. He has also been General Secretary of the powerful FPSA since 1969.

The framing of the 1991 Sugar Industry Decree was therefore aimed at not only inhibiting stoppages in the sugar industry but also counteracting the strong internal and international support the cane farmers had. This did not deter Felix Anthony from threatening that his union, the Fiji Sugar General Workers' Union, would take industrial action if cane was forcibly harvested or if cane farmers were intimidated by the police and other authorities (FT, 8 July 1991; 8 August 1991). With 2,000 members, this was the largest union in the sugar industry, ahead of the Fiji Sugar Tradesmens' Union, the Clerks' and Supervisors' Association and the union representing management staff, the Sugar Milling Staff Officers' Association.

Confrontation between sugar workers and FSC management was exacerbated in July 1991 when 1,000 workers were laid-off due to the lack of cane-supplies. At least a further 1,000 mill-workers protested at this action by stopping work until the FSC agreed to compensate for lost wages. (FT, 4 July 1991). The Sugar Milling Staff Officers' Association took a somewhat ambivalent stand by supporting calls for a general strike, giving lukewarm support to the sugar workers already on strike, yet also threatening industrial action among its field staff if they were intimidated by growers' organisations while preparing and organising sugar harvesting gangs (FT, 8 July 1991; 10 July 1991).

The 1991 crisis in the sugar industry escalated with riot police being deployed to Western Fiji's cane districts and claims from NFU Rakiraki branch President, Marika Silimaibau, that police and district officers were pressuring farmers to harvest ( $F T, 1$ June 1991). Doubts about police and army support for enforcing the decrees began to be raised after Fiji's President warned that soldiers might cut cane (FT, 5 June 1991). Although Ratu Viliame Tagivetua, the District Officer of $\mathrm{Ba}$, cited the new sugar decree to ban a proposed meeting of 10,000 farmers, Philip Arnfield, the new Police Commissioner did not see it as illegal. While many farmers were intimidated from attending, a private meeting of $2000 \mathrm{NFU}$ members called on government to revoke the decrees and resolved to seek solidarity from international trade unions (FT, 8 June 1991). The enactment of the decrees increased local awareness and support for the cane farmers original grievances. A similar pattern developed in Fiji's troubled goldmining industry.

\section{Industrial relations 'underground': the Vatukoula dispute}

On 4 June 1991 the Fiji Times ran an advertisement for Taniela Veitata, the Minister of Employment and Industrial Relations, in which he described Kavekini Navuso, the General Secretary of the recently registered Fiji Mine Workers Union (FMWU) as "like a man possessed". This battle of words fought in the newspapers was over Navuso's efforts to gain voluntary recognition for the FMWU by the Emperor Goldmining Company (managed by a former Australian shareholder, Western Mining Company). Refusal to grant recognition in Fiji's fourth biggest export industry led to union members going on strike on 23 February 
1991 (FT, 28 February 1991).

Like many industrial disputes, this issue was merely the tip of a whole range of grievances, many of which were long-standing and reflected not just problems with immediate working conditions, but were a protest about unsatisfactory living conditions in the mining town of Vatukoula. Even long-term underground miners are paid according to productivity which means that they might receive $\$ 400$, or only $\$ 100$, for two weeks' work. Wages are also depressed by the company's practice of taking deductions for various expenses, such as gelignite, overalls, boots, housing and electricity. Miners have also complained about not receiving overtime rates. A major source of discontent has been the practice of segregated grades of accommodation which means that several indigenous Fijian families live in sub-standard, overcrowded, poorly ventilated one-bedroomed houses.

The confrontation was accelerated by the FMWU claiming that the dismissal of President, Samuel Sanday and executive member, Kaveni Kau was victimisation ( $F T, 9$ November 1990). This came after their criticism of the company's tardiness in paying death compensation to the family of a miner who was crushed to death by a boulder (Interviews; FT, 5 November 1990; 9 November 1990; FTUC, 1990a, p.96). Attention was also drawn to poor safety and health conditions both underground and in Vatukoula. In their complaints about inadequate sick leave the FMWU claimed that the company insists workers return to "light duties" on half-pay to cut costs and to bolster its apparent image of a glowing health and safety record (FTUC 1990b; interviews).

It is no secret in Fiji that Emperor's chairman, Geoffrey Reid, has long been rigidly opposed to unionism (see Report ... at Vatukoula 18 April 1977; FT, 25 March 1991). Management has maintained that the union does not have the 50 percent of potential members required under the Trade Union Recognition Act while the FMWU claimed to have 899 signed up members in 1990 (FTUC 1990a, p.96). There has also been a discrepancy over the number believed to have supported the strike, with the union claiming that more than 700 workers out of a workforce of 1150 ( 221 are not miners) were on strike to the company's estimate of 420 (FT, 1 June 1991).

Other actions taken by management during the strike clearly demonstrated an unwillingness to work towards resolving long-standing industrial relations problems at Vatukoula. Reid has adamantly refused to enter into any conciliation with the strikers. Instead Emperor management declared that 440 strikers were dismissed from employment on 3 April. Striking miners claimed that the company hired local villagers to not only provide scab labour but also to attack picketing miners. It was also alleged that a local chief received considerable 'rewards' to provide this muscle for the company; a tactic apparently not new in breaking workers' solidarity at the mines.

Until the imposition of the decrees, the interim administration refused to take any direct action to resolve the dispute, although official actions and statements indicated where its support lay. Three months into the strike, 60 picketers were arrested. Although the High Court ruled on 24 March that picketing was legal as long as criminal acts did not occur, subsequent regulations under the sugar and economy decrees could be construed as outlawing picketing. Navuso also dismissed the MEIR's role in reaching an agreement with Emperor to re-employ 200 miners as a "confidence trick" aimed at breaking the union's stand (FT, 22 June 1991).

Throughout the crisis in the goldmining industry, Veitata insisted that there was no dispute ((FT, 5 November 1990; 4 June 1991) and that the union should first seek compulsory recognition under the Trade Disputes Act. Navuso however claimed that this denied the "union the right to seek mediation under the Trade Disputes Act on our real industrial 
grievances relating to employment and living conditions" (FT, 16 July 1991). The FMWU later agreed to seek compulsory recognition but insisted that first government appoint a conciliator. This stand was taken because the union had "no confidence in the ministry's impartiality" (FT, 16 July 1991). By August 1991, the MEIR finally recognised that an industrial dispute existed but still refused to recognise the FMWU as the legitimate representative of the strikers. Emperor Goldmining continued to boycott conciliation meetings.

Official views, as with the industrial unrest in the garment and sugar industries, also dismissed the mining strike as being politically motivated. Veitata suggested that the strike was prolonged intentionally by Navuso and supporters in the FLP/NFP Coalition to coincide with the sugar harvesting boycott "as part of their concerted efforts to destabilise the country" (FT, 4 June 1991). Union officials have not denied that there is a deep-seated political basis to this dispute but they have thrown the ball in the other court, pointing to long-standing political links between Emperor Goldmining and some members of the current regime (Fiji Labour Sentinel, March 1991).

The often-bandied bogey of indigenous Fijian domination by supposedly power-hungry Indian unionists has not been applicable to the goldmining dispute, as most of the miners are ethnic Fijians. Public support for their plight was strengthened when, at the miners' request, Methodist church leaders intervened to assist in reaching a solution. Rabuka also made it clear that he would not allow the army to be used against the strikers. The long duration of the strike would not have been possible without food and financial assistance from local and overseas unions and other supporters in Fiji. As with the sugar decree, the District Officer of $\mathrm{Ba}$ also decided to invoke provisions of the decree by barring the FMWU from mounting a public appeal in his district (FT, 1 June 1991).

\section{Dealing with officialdom}

The disputes outlined in this paper reveal the difficulties in resolving industrial conflict through the established industrial relations channels. Long before the coups, major unions, such as the FPSA, accused management and government ministries of deliberate slowness in resolving grievances and disputes (Leckie, 1988, pp.162-4). This has been compounded since the coups, not only because of the increased politicisation of official intervention in industrial relations, but due to personnel shortages and the resignation of experienced senior labour officers.

Since the coups several unions have complained of the MEIR's reluctance to enforce collective agreements and the rejection of disputes without any valid reasons being given (FTUC, 1990, p.56). Frustrated workers have two main options: taking strike action or entering into expensive and even more time consuming litigation through the High Court.

The FTUC has also complained of the MEIR's bias towards employers. Alternatively when arbitration awards have been in the union's favour, this has been challenged by employers through judicial reviews. This delays any settlement being reached and has compelled unions to dip into their often limited funds to meet legal expenses. As noted, delays in enforcing labour related legislation have been especially prevalent in the rapidly expanding garment industry. The FAGW has also criticised labour officers' bias against workers registering complaints. Most garment workers who are prepared to report a grievance to the Ministry have first to overcome shyness and fear of victimisation by employers. Druavesi claimed that the MEIR was inconsistent in its criteria for accepting or rejecting a 
trade dispute. A reported dispute over the dismissal of three workers from Lotus Garments was rejected by the Ministry on the grounds that the Registrar of Trade Unions claimed that it was illegal for an industrial association to strike. Instead the Ministry suggested that individuals could lodge complaints and that it would consider intervening if there was a joint approach from management and the workers. However government had intervened in two previous strikes within the garment industry. Druavesi also maintained that the Trade Disputes Act (before November 1991) applied to industrial associations and not just trade unions (FT, 9-18 November 1990).

Unions have also reported unnecessary delays by the Registrar of Trade Unions in either registering new associations such as those in the mining and garments industries or in accepting amendments to the constitutions of existing unions. For example, Chaudhry warned the Registrar that if an eight month delay to an amendment of the FPSA's constitution was not dealt with, legal action would be taken (correspondence to Registrar: S10/619: 27 November 1990). The technical grounds of typing errors in the application were given for a six months delay in accepting registration of the FMWU (FT, 11 January 1990).

\section{From an 'uneasy' resolution to labour 'reforms'}

The mid-1991 crisis in Fiji's industrial relations involved a number of related issues which both complicated and also contributed towards a temporary 'uneasy' resolution. Of significance here was the growing rift between Rabuka and Mara's cabinet. Rabuka's interest in labour relations underwent some dramatic changes from when the military regime had been responsible for detaining and repeatedly harassing trade unionists, workers, and cane farmers (Leckie, 1991) to sympathy towards striking nurses and garment workers in 1990 and mine workers and cane farmers in 1991. A cynical interpretation of this apparent change of tune towards the labour movement might point to opportunism and the populist image Rabuka seeks to maintain. The same day Rabuka resigned as Fiji's military commander to become Co-Deputy Prime Minister, he also took the new role of industrial relations troubleshooter to try to avert a threatened national strike (FT, 12 July 1991). Rabuka had earlier called upon the government to resign, claiming that it was out of touch with the people. Much of his attack focused on the administration's bungling of issues closely connected to industrial relations in Fiji (FT, 8 June 1991).

If Rabuka's support comes predominantly from large sections of the indigenous Fijian population, then he must have noticed that contrary to many expectations the aftermath of the coup did not see a weakening of indigenous Fijian involvement in trade unions. This was despite several attempts by the administration and some employers to encourage and promote ethnically based trade unions, such as the Viti Civil Servants Association, (see Leckie, 1991, pp.61-4). Ethnic Fijians, both in villages and towns, have been equally hit by the post-coup economic downturn. The promulgation of a new constitution in 1990, has given way to a vast assortment of new political parties, reflecting not only growing political discontent, but also disillusionment about the benefits the coup was supposed to bring to the lives of indigenous Fijians. Plans to introduce VAT were widely unpopular, even among some government ministers, such as the Solicitor-General (FT, 21 June 1991).

The FTUC's initial response to the May decrees was to seek dialogue with the Prime Minister, while the NFU called for industry-wide discussions. At a labour conference on 21 June FTUC affiliates called for a general strike on 16 July to protest against the labour decrees 
and the proposals to introduce VAT and labour reforms. Although the proposed strike was declared illegal by the administration, it drew support from non-FTUC unions, with the exception of some ethnically based and pro-Taukei ${ }^{4}$ unions.

Besides the threat of local industrial action the FTUC called upon international affiliates for support. Such measures have been a powerful card the FTUC has played since the coups (Leckie, 1991). Vanderveken, General Secretary of the ICFTU was quick to condemn what he regarded as an erosion of workers' rights, particularly because Fiji's interim administration had "specifically and unequivocally agreed" to ICFTU missions during 1988 and 1989 not to make any changes to existing trade union legislation and to abide by the relevant international and ILO conventions (FT, 10 July 1991). In a letter to Ratu Mara he warned that the ICFTU and the European Trades Union Congress were recommending that the European Community suspend all economic aid to Fiji. International affiliates of Fiji's trade unions were highly likely to impose trade and communication bans if repressive legislation was put into practice to resolve the industrial crisis.

Pressure from workers within and outside Fiji was critical in the administration having to shelve the National Economy Protection decrees. Following a meeting held on 12 July between Chaudhry, Columbus, Rabuka and Gaunilau, the unions agreed to lift the strike threat, while the President stated that a conference would be held to settle the sugar dispute, that the decrees would be suspended, and an attempt would be made to resolve the Vatukoula dispute. Agreement was also reached to refer details of the labour reform changes and VAT to a tripartite meeting of the Labour Advisory Board.

This resolution was greeted by many unions as a victory for workers, particularly after government also announced that it would restore recognition of the FTUC as the national union body. However few of the agreements reached on 12 July were implemented. By early 1992, the Vatukoula dispute remained unresolved. It seems likely VAT will be introduced in 1992. The interim government proceeded with its plans to introduce labour reforms, now with greater support from Fiji's employers' associations (FT, 2 September 1991, 6 November 1991). This was a departure from indications before 1991 when many employers endorsed FTUC calls for a comprehensive review of labour legislation along the lines of an ILO sponsored (the Drake) report. The lack of resolution within the sugar industry precipitated the NFU into holding a strike during 5-7 November, just after the interim government promulgated decrees announcing labour reforms as outlined at the 1991 NES (Fiji Republic Gazette, 5(77), 1 November 1991). The new reforms also clearly aimed to weaken Chaudhry's powerful role, by prohibiting an office holder from serving in more than one union or industrial association. ${ }^{5}$ Plans to abolish wages councils were shelved, although employers' organisations are pushing for a review of their operations (FT, 6 November 1991).

Again, the see-saw pattern of post-coup industrial relations was set in action, with the FTUC unsuccessfully seeking dialogue with the Prime Minister, pursuing international solidarity support and threatening a general strike in February 1992. Both forms of industrial action are illegal under the November decrees.

The Taukei refers to the indigenous people of Fiji but here it refers to the Taukei Movement, a group which took an extreme stand on the primacy of indigenous political domination. This led to efforts to destabilise the Coalition government before the 1987 coup.

sOther provisions, besides those outlined in this paper with regard to the 1991 NES, included the requirement of a secret ballot under close government supervision before taking strike action. Industrial action, including seeking overseas support is only legal if votes are cast for this by 50 percent of the union membership. The ballot is valid for six weeks. Certain categories of employees are prevented from forming or joining union. Penalties for breach of the new decrees are a $\$ 2,000$ fine or 12 months imprisonment and those convicted may be barred from being a trade union official for two years. 


\section{Conclusion}

The changing climate of industrial relations in Fiji has reflected not only changes in domestic politics, that is one strategy by a regime determined to maintain its power, but also is indicative of international trends in industrial relations. While many workers and trade unions perceive restrictions against trade union organisation and operations as a threat to workers' collective bargaining power and the thin edge which depresses wage levels even further, most politicians, employers and their advisers, clearly welcome these changes.

Fiji's government argues that the restructuring of labour relations are a response to the increasing integration of Fiji's economy into the international market (FT, 5 November 1991). Since the late 19th century, Fiji's political economy has been largely determined by international forces, but this was as a colonial state dependent upon the prices its export commodities, sugar, copra and gold could fetch on the world market. Since independence the growing tourist trade offered a means for Fiji to break out of its dependence upon traditional export earners. This was always a fickle industry and the coups, along with the recent economic recession in Australia and New Zealand facilitated a fall in tourists. Fiji's drive towards export-orientated industrialisation is not just a reversal of earlier import-substitution and protectionism in the manufacturing sector but also a policy to widen its revenue earners.

It would be naive to suggest that the move towards a more internationally competitive economy has only emanated from within Fiji. As many third world countries have found when facing the day of reckoning with international lending agencies, there has been considerable pressure to restructure economies along internationally market competitive lines. For example, the European Community has allocated a \$13.3 million grant and loan to fund the establishment of Fiji's first tax-free zone (FT, 20 September 1990) near Suva. In the case of Fiji, the coups were the catalyst which hastened this process. This coincided with a period in which international manufacturers were seeking new areas of investment. In particular Fiji's tax free factory scheme, especially in the garment industry, offered potential for investment from manufacturers in New Zealand and Australia. Economic restructuring, both within and outside the Pacific Islands, aimed to make such economies more 'fiscally responsible' and attractive to local and international investment through restructuring the labour market and industrial relations machinery, introducing new taxation measures such as VAT, slashing public spending and restructuring the public sector.

While the labour restructuring is geared towards the export sector, it is also intended to control the traditional areas of Fiji's formal labour force. The severity of the decrees and the singling out of the sugar industry indicated this. Economic and other rationale (such as supposedly making unions more 'democratic') may be given by government apologists, but political considerations are also behind these attempts to control the labour force. Far from being deregulated, as Fiji moves into the nineties, workers face even greater state control over their organisations and the labour relations system. 


\section{References}

Unpublished sources: Interviews conducted January 1990 and May 1991. In some cases due to the sensitive nature of the subject exact sources are not given.

Barr, K. (1990), Poverty in Fiji, Suva, Fiji Forum for Peace and Justice.

Cameron, J. (1988), The Political Economy of Recent Events in Fiji, Capital and Class, $33: 1-5$

Chandra, R. (1988), Fiji's Tax Free System and the New International Division of Labour, Suva, School of Social and Economic Development, University of the South Pacific, Working Paper 11.

Cole, J. ( 1991), Report in Service Worker (Southern region), 8(34): 21 September.

Fiji Independent News Service, (1990-1).

Fiji Labour Sentinel, (1987-91).

Fiji Public Service Association (1978), Annual Report.

Fiji Republic Gazettes, (as cited).

Fiji Times (FT), (1987-91).

Fiji Trades Union Congress (1987-1991), Official directories.

Fiji Trades Union Congress (1990a), Report of activities February 1988-May 1990.

Fiji Trades Union Congress (1990b), Survey of working conditions at Emperor Gold Mines and Western Mining Corporation (Fiji) Ltd. Joint venture in Vatukoula, Fiji. AFF35/23: 2/2/90.

Gillion, K. (1977), The Fiji Indians: Challenge to European Dominance, 1920-1946, Melbourne, Oxford University Press.

Hince, K. (1990), Trade Unionism in Fiji in 1990: After Twenty Years of Independence and Two Military Coups, Wellington, Industrial Relations Centre, Victoria University of Wellington, Working paper 4/90.

Howard, M.C. (1985), The Evolution of Industrial Relations in Fiji and the Reaction of the Public Employees' Unions to the Current Economic Crisis, South Pacific Forum, 2(2): 119-123.

International Labour Organisation (1982), Rural Workers' Organisation in Fiji, Geneva, International Labour Office, Workers' Education Programme. 
Islands Business (1987-91).

Knapman, B. (1988), Afterword: The Economic Consequences of the Coups, In R. Robertson and A. Tamanisau, Fiji. Shattered Coups, Sydney, Pluto Press: 157-90.

Leckie, J. (1988), Confrontation with the State: Industrial Relations and the Fiji Public Service Association during the 1970s and 1980s, South Pacific Forum, 4(2): 137-179.

Leckie, J. (1990a), Workers in Colonial Fiji, 1870-1970, In C. Moore, J. Leckie and D. Munro (Eds.), Labour in the South Pacific, Townsville, James Cook University of Northern Queensland Press: 47-66.

Leckie, J. (1990b), Development for the Workers? the Reaction of Civil Service Unions to State Policies in Fiji, In M.C. Howard and T. Wheelwright (Eds.), The Struggle for Development. Essays in Honour of Ernst Utrecht, Burnaby: International Studies Programme/Simon Fraser University: 85-104.

Leckie, J. (1991), State Coercion and Public Sector Unionism in Post-coup Fiji, New Zealand Journal of Industrial Relations, 16:49-71.

National Economic Summit draft papers (1991), Addresses by the Prime Minister, Sir Kamisese Mara; the Minister of Finance and Economic Planning, Josevata Kamikamica; the Minister of Trade and Commerce, Berenado Vunibobo, Suva. (referred to as NES 1991).

Plange, N. (1990), Rendezvous with the Cane Growers. The Restructuring of the Fiji Sugar Industry, 1980-84. Suva, School of Social and Economic Development, University of the South Pacific, Working paper 17.

Prasad, S. (1989), Trade Unions in the Changing Socio-economic Environment in Fiji, Suva, School of Social and Economic Development, University of the South Pacific, Working paper 13.

Report of the Committee to Examine the Economics of the Gold Mining Industry at Vatukoula, (18 April 1977), Suva (Fiji National Archives).

Reserve Bank of Fiji (1991), News Review. 